\title{
UJI AKTIVITAS ANTI BAKTERI EKSTRAK METANOL DAUN Baccaurea macrocarpa TERHADAP Escherichia coli DAN Salmonella typhi
}

\author{
Fitri Helmalia $^{1}$, Vivi Mardina ${ }^{1 *}$, Fadhliani $^{1}$, Lendawati $^{2}$ \\ ${ }^{1}$ Program Studi Biologi, Fakultas Teknik, Universitas Samudra, Meurandeh, Langsa, 24416 \\ ${ }^{2}$ Politeknik Kesehatan Tanjungkaran \\ *corresponding author : vmardina@unsam.ac.id
}

\begin{abstract}
Antibiotics are drugs that are used to inhibit bacteria production. The long-term use of antibiotics can cause resistance problems. As a consequence, it is necessary to find alternative antibiotics that are derived from plants. The alternative antibiotics are considered safer, relatively cheap, and easy to obtain. One of the herbal plants used is Baccaurea macrocarpa. This study aimed to identify the secondary metabolites of B.macrocarpa, the effect of methanol extract from B.macrocarpa leaves on the growth of Escherichia coli and Salmonella typhi bacteria, and to measure the optimal concentration of the sample against E.coli and S.typhi bacteria growth. The study has been conducted for 3 months at the Universitas Samudra laboratory. The method used was the well method with E. coli and S.typhi bacteria test. Each treatment of the methanol extract of B. macrocarpa leaves with a concentration of 20\%, 30\%, and $40 \%(\mathrm{~g} / \mathrm{ml})$. Ciprofloxacin and sterile distilled water were positive and negative control. The results obtained the concentration of $40 \%$ $(\mathrm{g} / \mathrm{mL})$ as the optimal concentration to inhibit the growth of E. coli and S.typhi bacteria with the resulting inhibition zone of $6.3 \mathrm{~mm}$ and $5 \mathrm{~mm}$. The study concluded that the B. Macrocarpa leaf extract could be developed as a basic ingredient for antibiotics.
\end{abstract}

Keywords: Antibacterial activity, Baccaurea macrocarpa, methanol extract

\begin{abstract}
ABSTRAK
Antibiotik merupakan obat yang digunakan untuk menghentikan reproduksi bakteri. Penggunaan antibiotik komersial dalam jangka panjang dapat menimbulkan masalah resistensi, sehingga diperlukan alternatif antibiotik yang berasal dari tanaman dengan alasan lebih aman, relatif murah dan mudah diperoleh. Salah satu tanaman herbal yang digunakan adalah Baccaurea macrocarpa. Penelitian ini bertujuan untuk mengidentifikasi metabolit sekunder pada B.macrocarpa, mengevaluasi pengaruh ekstrak metanol daun B.macrocarpa untuk menginhibisi pertumbuhan Escherichia coli dan Salmonella typhi serta mengukur konsentrasi optimum sampel untuk menginhibisi pertumbuhan E.coli dan S.typhi. Penelitian ini telah dilakukan selama 3 bulan di laboratorium Universitas Samudra. Metode yang digunakan adalah metode difusi sumuran. Setiap perlakuan diberi ekstrak metanol daun B. macrocarpa dengan berkonsentrasi $20 \%$, $30 \%$ dan $40 \%(\mathrm{~g} / \mathrm{ml})$. Ciprofloxacin dan akuades steril telah digunakan sebagai kontrol positif dan negatif berturut-turut. Hasil yang diperoleh adalah konsentrasi $40 \%(\mathrm{~g} / \mathrm{ml})$ merupakan konsentrasi optimum untuk menginhibisi tumbuhnya bakteri E.coli dan S.typhi dengan zona bening (hambat) yang dihasilkan $6,3 \mathrm{~mm}$ dan $5 \mathrm{~mm}$. Secara keseluruhan, penelitian telah menyimpulkan bahwa ekstrak daun Baccaurea Macrocarpa berpotensi untuk dikembangkan sebagai bahan dasar antibiotik.
\end{abstract}

Kata Kunci: Aktivitas antibakteri, Baccaurea macrocarpa, ekstrak methanol

\section{PENDAHULUAN}

Penggunaan antibiotik ditujukan untuk menghentikan reproduksi atau membunuh bakteri, dan juga sebagai sistem pertahanan alami tubuh. Penggunaan antibiotik jangka panjang akan berpotensi menimbulkan 
resistensi serta efek negatif yang tidak dikehendaki. Oleh karena itu, dokter menyarankan setiap pengguna antibiotik harus mengikuti strategi peresepan antibiotik (Fernandez, 2013).

Penggunaan antibiotik yang berasal dari tumbuhan dapat berfungsi sebagai antioksidan. Hal ini disebabkan karena adanya metabolit sekunder seperti senyawa fenolik (polifenol maupun fenol). Menurut Mohamad et al. (2012) kandungan metabolit sekunder pada suatu tumbuhan berbanding lurus dengan kemampuannya sebagai antioksidan. Senyawa fenolik yang dimaksud dapat berupa polifenol, fenol, tanin dan flavonoid. Malangngi et al. (2012) menemukan bahwa tanin dan flavonoid sangat efektif sebagai antioksidan. Mardina et al. (2020a) yang menyatakan flavonoid, alkaloid dan steroid dapat bertindak sebagai antioksidan. Menurut beberapa literatur (Akhmadi \& Sumarmiyati, 2015; Gunawan et al. 2016; Novitaria et al., 2016) tanaman tampoi (Baccaurea macrocarpa) dapat digunakan sebagai antibiotik alami karena adanya aktivitas antioksidan dari metabolit sekunder yaitu flavonoid.

B.macrocarpa atau dikenal tampoi merupakan genus Baccaurea yang digemari masyarakat karena buahnya yang manis. Tampoi merupakan tanaman dikotil dengan karakteristik tipe daun majemuk berbentuk jorong, tepi daun rata, simetri, warna daun bagian atas hijau tua, mengilap, sedangkan bagian bawahnya berwarna hijau lebih muda dari bagian atas serta tidak mengilap, ujung daun meruncing dengan pangkal daun tumpul, arah daun menghadap ke atas, warna tangkai daun coklat (Akhmadi \& Sumarmiyati, 2015). Tirtana et al. (2013) melaporkan bahwa tampoi mengandung flavonoid, alkaloid dan saponin. Metabolit sekunder ini dapat dimanfaatkan sebagai antioksidan dan juga memiliki efek penghambat pertumbuhan bakteri.

Berdasarkan uraian yang dipaparkan, tujuan dari riset ini adalah untuk mengevaluasi keaktifan metabolit sekunder daun tampoi sebagai antibakteri yang dimaserasi menggunakan pelarut metanol terhadap Escherichia coli serta Salmonella typhi.
Pemilihan kedua bakteri ini didasarkan bakteri tersebut sering menyerang sistem pencernaan pada manusia melalui makanan dan minuman (Rohdiana et al., 2013).

\section{METODE}

Penelitian ini dilaksanakan di laboratorium Universitas Samudra, Provinsi Aceh dengan material utama adalah daun tampoi (Baccaurea macrocarpa). Bahan pendukung lainnya yaitu metanol, alkohol 70\%, bakteri uji (Escherichia coli dan Salmonella typhi), akuades steril, Nutrient Agar (NA), Nutrien Broth (NB), kertas saring, spiritus, aluminium foil.

\section{Persiapan Sampel}

Daun B. macrocarpa dikumpulkan dan dicuci hingga bersih. Kemudian daun ditiriskan dan dikering anginkan selama \pm 10 hari. Sampel dihaluskan menggunakan blender hingga berbentuk bubuk. Serbuk tersebut kemudian diayak (ukuran ayakan $\pm 0,01 \mathrm{~cm}$ ) (Yunus et al., 2018). Serbuk yang dihasilkan dimaserasi menggunakan metanol sebagaimana yang disarankan oleh Mardina et al. (2019), Mardina et al. (2020b). Sebanyak $150 \mathrm{~g}$ serbuk tampoi dilarutkan pada metanol (750 ml), kemudian dibiarkan selama 3 hari sebelum disaring menggunakan Whatman filter paper No.1. Evaporasi dilakukan secara manual pada suhu di bawah $40{ }^{\circ} \mathrm{C}$.

\section{Uji Fitokimia}

Uji fitokimia ekstrak metanol $B$. macrocarpa terdiri uji flavonoid, alkaloid, saponin, tanin, steroid dan terpenoid. Sebelum pengujian disiapkan larutan stok ekstrak metanol dengan cara melarutkan ekstrak pada $10 \mathrm{ml}$ akuades. Penentuan hadirnya alkaloid dilakukan dengan penambahan 3-5 tetes larutan $\mathrm{H}_{2} \mathrm{SO}_{4}$ pada larutan ekstrak, dihomogenkan dan diamkan hingga terjadi pemisahan. Kemudian diambil lapisan asam dan tambahkan reagen dragendorf. Uji positif untuk alkaloid ditunjukkan dengan terbentuk endapan jingga atau coklat. Uji flavonoid dilakukan dengan menambahkan bubuk Magnesium (Mg) dan asam klorida pekat (5 tetes) pada larutan ekstrak. Jika ada warna jingga/ merah, mengkonfirmasikan adanya 
flavonoid (Mardina et al., 2020a; Mardina et al., 2020b; Mardina et al., 2020c; Juli et al., 2013).

Uji saponin dilakukan dengan melarutkan larutan ekstrak pada akuades, dipanaskan, setelah dingin dikocok hingga berbusa sebelum ditambah beberapa tetes $\mathrm{HCl}$. Hadirnya busa selama \pm 10-15 menit mengkonfirmasikan hadirnya saponin pada ekstrak (Mardina et al., 2020b).

Uji steroid dan terpenoid dilakukan dengan cara $1 \mathrm{ml}$ sampel dilarutkan ke dalam akuades, kemudian ditambahkan laruran asam asetat $\left(\mathrm{CH}_{3} \mathrm{COOH}\right)$ dan asam sulfat $\left(\mathrm{H}_{2} \mathrm{SO}_{4}\right)$. Terbentuknya warna merah mengkonfirmasi senyawa terpenoid hadir pada ekstrak dan jika terbentuknya warna biru/ ungu mengkonfirmasi adanya senyawa steroid (Day et al., 2018). Uji tanin yaitu $2 \mathrm{ml}$ larutan sampel $+\mathrm{FeCl}_{3}(1 \%)$ sebanyak 2 tetes. Hadirnya senyawa tanin dikategorikan positif jika terbentuk warna biru kehitaman terbentuk (Mardina et al., 2020b; Mardina et al., 2020c).

\section{Uji Keaktifan Ekstrak sebagai Antibakteri}

Keefektifan sampel sebagai antibakteri telah diuji dengan mengadopsi metode difusi sumuran. Kultur dan pembuatan inokulum E.coli dan S.typhi dilakukan mengikuti prosedur yang disarankan Mardina et al. (2015); Mardina \& Yusof (2018). Cawan Petri diisi media NA hingga mengeras, kemudian diambil $0,1 \mathrm{ml}$ biakan bakteri (biakan bakteri pada media NB) diinokulasi menggunakan batang L. Kemudian dibuar sumuran dengan diameter $6 \mathrm{~mm}$. larutan ekstrak uji adalah 20\%, $30 \%, 40 \%(\mathrm{~g} / \mathrm{ml})$ diinjeksikan ke sumuran. Ciprofloxacin adalah kontrol positif dan akuades steril adalah kontrol negatif (Muharni, 2017). Pengukuran zona hambat dilakukan setelah inkubasi 24 jam (Rohdiana et al., 2013). One Way Anova (5\% signifikan) digunakan untuk analisa data.

\section{HASIL DAN PEMBAHASAN Skrining Awal Fitokimia}

Hasil yang diperoleh yaitu fitokimia daun B.marcocarpa ditampilkan pada Tabel 1. Menurut hasil yang diperoleh, ekstrak terkonfirmasi hadir senyawa flavoniod dan alkaloid yang berperan sebagai antibakteri pada suatu tumbuhan. Flavonoid bekerja dengan protein ekstraseluler untuk membentuk senyawa kompleks yang dapat merusak membran sel bakteri kemudian senyawa intraselulernya dikeluarkan (Ngajow et al, 2013). Sedangkan alkaloid dengan struktur basa aromatik rantai samping bersinergis dengan kompleks nitrogen pada DNA dan dinding sel (bakteri) untuk menghancurkan terbentuknya enzim dihidrofolat reduktase yang akhirnya akan menghadang asam folat terbentuk. Pada alkaloid juga terkandung squalamine yang mampu membocorkan sitoplasma sel sehingga terjadi depolarisasi pada membran (sel) Proses depolarisasi akhirnya menyebabkan bakteri mati karena rusaknya dinding bakteri (Muharni et al., 2017).

Tabel 1. Hasil Fitokimia daun B.macrocarpa (metanol sebagai pelarut pada proses maserasi)

\begin{tabular}{clllc}
\hline No. & Pemeriksaan & Pereaksi & Hasil & Keterangan \\
\hline 1 & Flavonoids & Bubuk $(\mathrm{Mg})$ & Terbentuk warna jingga & + \\
2 & Alkaloids & Dragendrof & Terbentuk endapan (jingga warnanya) & + \\
3 & Saponins & HCL & Tidak ada busa & - \\
4 & Steroids & Asam asetat dan sulfat & Tidak ada warna jingga & - \\
5 & Terpenoid & Asam asetat dan sulfat & Tidak ada warna merah & - \\
6 & Tanin & Mg, Klorida $1 \%$ & Tidak ada warna biru (tua) & - \\
\hline
\end{tabular}

\section{Uji Aktivitas Antibakteri}

Pengujian aktivitas antibakteri pada sampel B. macrocarpa menyimpulkan bahwa semua konsentrasi ekstrak metanol daun tampoi $(20 \%, 30 \%, 40 \%, \mathrm{~g} / \mathrm{ml})$ memiliki zona hambat (Gambar 1 dan 2). Adanya zona bening yang terbentuk dan disebut sebagai zona hambat terhadap pertumbuhan bakteri. Uji keefektifan ekstrak dibandingkan dengan akuades steril dan ciprofloxacin dan hasil disajikan pada Tabel 2 dan 3. 


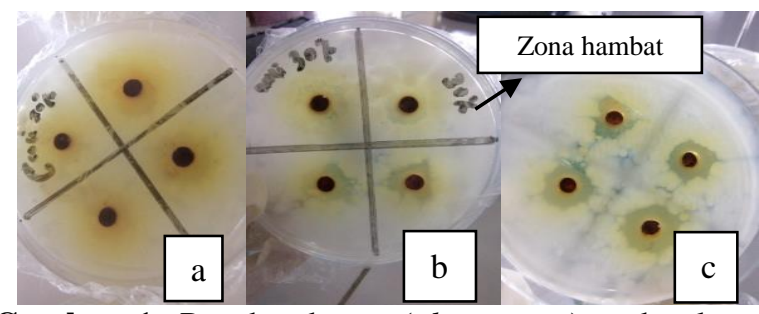

Gambar 1. Penghambatan (clean zone) pada ekstrak daun metanol daun B.macrocarpa dengan konsentrasi $20 \%$ (a), $30 \%$ (b), c. $40 \%$ (c) terhadap bakteri $E$. coli.

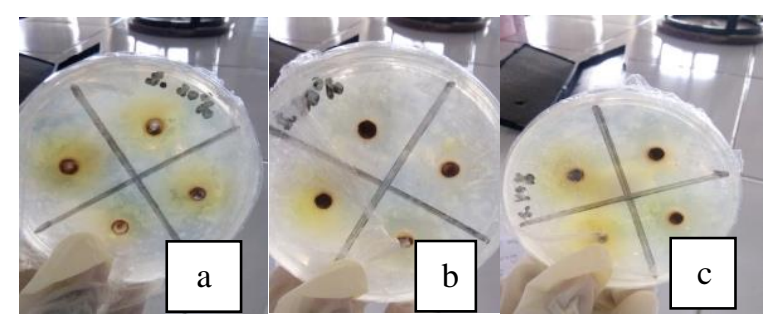

Gambar 2. Penghambatan (clean zone) pada ekstrak daun B.macrocarpa dengan konsentrasi $20 \%$ (a), $30 \%$ (b), c. $40 \%$ (c) melawan S.typhi

Tabel 2. Hasil uji ekstrak metanol daun B.macrocarpa menginhibisi tumbuhnya bakteri E.coli

\begin{tabular}{|c|c|c|c|c|c|}
\hline \multirow[t]{3}{*}{$\begin{array}{c}\text { Konsentrasi } \\
(\%)\end{array}$} & \multirow{2}{*}{\multicolumn{3}{|c|}{$\begin{array}{c}\begin{array}{c}\text { Diameter zona } \\
\text { hambat }(\mathrm{mm})\end{array} \\
\text { Replikasi }\end{array}$}} & \multirow[t]{3}{*}{ Rerata } & \multirow{3}{*}{$\begin{array}{l}\text { Std } \\
\text { Dev }\end{array}$} \\
\hline & & & & & \\
\hline & 1 & 2 & 3 & & \\
\hline 0 & 0 & 0 & 0 & $0,00^{\mathrm{d}}$ & 0,000 \\
\hline 20 & 3 & 4 & 3 & $3,33^{c}$ & 0,573 \\
\hline 30 & 4 & 4 & 4 & $4,00^{\mathrm{b}}$ & 0,000 \\
\hline 40 & 7 & 6 & 6 & $6,33^{\mathrm{a}}$ & 0,577 \\
\hline
\end{tabular}

Tabel 3 Hasil uji ekstrak methanol daun B.macrocarpa terhadap pertumbuhan bakteri S.typhi

\begin{tabular}{cccccc}
\hline Konsentrasi & $\begin{array}{c}\text { Diameter zona } \\
\text { hambat }(\mathbf{m m})\end{array}$ & Rerata & \\
\cline { 2 - 4 }$(\boldsymbol{\%})$ & \multicolumn{3}{c}{ Replikasi } & & $\begin{array}{c}\text { Std } \\
\text { Dev }\end{array}$ \\
\cline { 2 - 4 } & $\mathbf{1}$ & $\mathbf{2}$ & $\mathbf{3}$ & & \\
\hline 0 & 0 & 0 & 0 & $0,000^{\mathrm{d}}$ & 0,000 \\
20 & 2,1 & 2 & 2 & $2,033^{\mathrm{c}}$ & 0,040 \\
30 & 5 & 4,1 & 4 & $4,367^{\mathrm{b}}$ & 0,440 \\
40 & 5 & 5 & 5 & $5,000^{\mathrm{a}}$ & 0,000 \\
\hline
\end{tabular}

Ket : Nilai (rerata \pm SD) dengan huruf yang sama menunjukkan tidak adanya perbedaan yang nyata

Tabel 2 dan 3 ekstrak metanol daun B.macrocarpa menunjukkan adanya perbedaan signifikan pada setiap konsentrasi. Hal ini diperjelas pada Gambar 3.

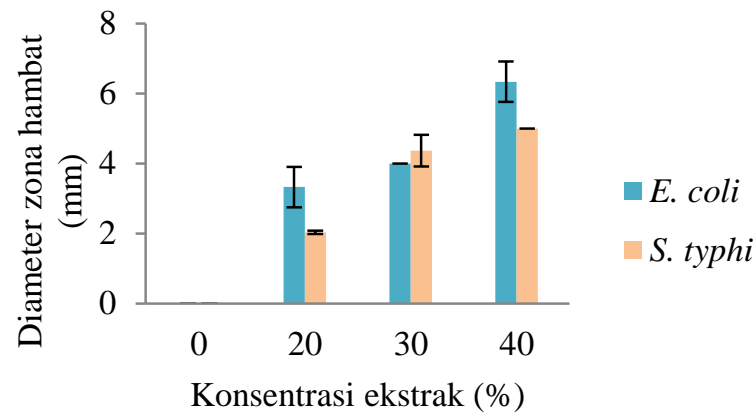

Gambar 3. Perbandingan keefektifan ekstrak melawan bakteri E.coli dan S.typhi pada variasi disertai Standar deviasi

Berdasarkan penelitian yang telah dilakukan, diketahui bahwa konsentrasi ektrak daun B.macrocarpa berpengaruh terhadap besarnya diameter zona hambat pertumbuhan bakteri E.coli dan S.typhi. Penelitian menggunakan konsentrasi 20\%, 30\%, 40\% $(\mathrm{g} / \mathrm{ml})$ karena didasarkan pada penelitian Yunus et al. (2018) yang menguji ekstrak metanol buah tampoi (5\%, 10\% dan $20 \%$ $(\mathrm{g} / \mathrm{ml})$, konsentrasi yang digunakan) dengan besar zona hambat 5,01 mm, 7,82 dan 9,21 mm untuk bakteri E.coli dan $0 \mathrm{~mm}, 0,43 \mathrm{~mm}$ dan 6,40 mm untuk S.typhi. Pada penelitian ini, konsentrasi ekstrak metanol daun B.macrocarpa ditingkatkan dengan tujuan untuk mengetahui nilai optimum pengaruh ekstrak pada kedua bakteri.

Gambar 3 menunjukkan bahwa peningkatan zona hambat berbanding lurus dengan peningkatan konsentrasi. Tresia (2016) menjelaskan bahwa jika konsentrasi ditingkatkan maka akan mempengaruhi hasil antibakteri (daya hambatnya). Hal ini diduga karena tingginya kadar metabolit sekunder sebagai zat aktif.

\section{Perbandingan konsentrasi maksimum ekstrak metanol daun B.macrocarpa terhadap antibiotik komersial}

Hasil aktivitas antibakteri tertinggi dari ekstrak metanol daun $B$. macrocarpa dibandingkan dengan antibiotik komersial (ciprofloxacin) yang ditampilkan pada Gambar 4. Hasil pengukuran zona hambat ekstrak methanol daun $B$. macrocarpa dengan 
konsentrasi $40 \%$ berpotensi sebagai bahan dasar antibiotik baru terhadap E. coli dan $S$. typi. Hal ini dapat dilihat dari hasil zona hambat yang terbentuk, untuk $E$. coli adalah $6,3 \mathrm{~mm}$ dan $5 \mathrm{~mm}$ untuk $S$. typi, sedangkan yang terbentuk dari ciprofloxacin sebesar 1,1 $\mathrm{mm}$. Perbedaan zona hambat antara ekstrak methanol daun B. macrocarpa pada $40 \%$ (g/ml) dengan kontrol (+) adalah berkisaran antara 5,2 $\mathrm{mm}$ dan 3,9 $\mathrm{mm}$.

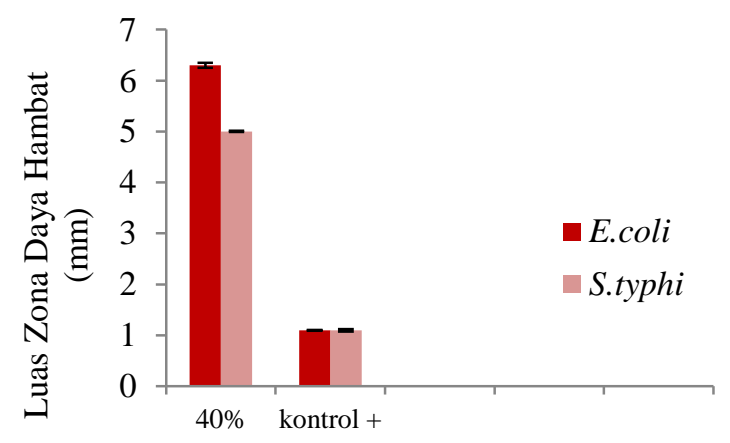

Konsentrasi Ekstrak

Gambar 4. Perbandingan konsentrasi tertinggi $40 \%$ dengan antibiotik komersial

Pemilihan ciprofloxacin sebagai standar antibiotik karena antibiotik ini bersifat luas spektrumnya untuk menghambat kebanyakan bakteri, baik gram (-) maupun (+). Mekanisme kerja ciprofloxacin adalah mengganggu ribosom (subunit 30S) yang akhirnya akan mengganggu terbentuknya protein (sintesis) (Purnamasari, 2018).

\section{PENUTUP}

Penelitian ini menyimpulkan bahwa ekstrak metanol daun Baccaurea macrocarpa memiliki pengaruh signifikan terhadap pertumbuhan bakteri Escherichia coli dan Salmonella typhi.

\section{DAFTAR PUSTAKA}

Akhmadi, N.R., Sumarmiyati. (2015). Eksplorasi dan karakterisasi buah kapul (Baccaurea macrocarpa) di Kabupaten Kutai Barat, Kalimantan Timur. Prosiding Seminar Nasional Masyarakat Biodiversitas Indonesia, 1 (4): 923-929
Day, D.W.R., Erwin, Astuti, W. (2018). Uji toksisitas dengan metode BSLT ekstrak kasar kulit batang tampoi Baccaurea macrocarpa). Prosiding Seminar Nasional Kimia 2018, Kimia FMIPA Unmul. ISBN 97860250927 No.17

Fernandez, B.A.M. (2013). Studi penggunaan antibiotik tanpa resep di Kabupaten Manggarai barat - NTT. Calyptra: Jurnal ilmiah mahasiswa Universitas Surabaya, 2 (2): 1 - 17

Gunawan, Tatik, C., Sobir, Sulistijorini. (2016). Review: fitokimia genus Baccaurea sp. Bioeksperimen 2(2): 96 110

Malangngi, L.P., Sangi, M.S., Paendong J.J.E. (2012). Penentuan kandungan tanin dan uji aktivitas antioksidan ekstrak biji buah alpukat (Persea americana Mill.). Jurnal Mipa Unsrat. 1(1):5-10.

Mardina, V. \& Yusof, F. (2018). Skim Latex Serum as an Alternative Nutrition for Microbial Growth. In: Multifaceted Protocol in Biotechnology. Springer, Singapore.

Mardina, V., Al Fajar, B., Fitriani. (2019). Potency of phytomedicine Sphagneticola trilobata extract as chemopreventive agent on the cases of breast cancer mice 7,12 Dimetilbenz (a) Antrasena induced. Yarsi Medical Journal, 27(2), 52 - 61

${ }^{a}$ Mardina V, Ilyas S, Harmawan T, Halimatussakdiah H, Tanjung M (2020) Antioxidant and cytotoxic activities of the ethyl acetate extract of Sphagneticola trilobata (L.) J.F. Pruski on MCF-7 breast cancer cell. J Adv Pharm Technol Res 11 (3): 123 - 127.

${ }^{\mathrm{b}}$ Mardina, V., Halimatussakdiah, Harmawan, T., Ilyas, S., Tanjung, ., Aulya, W., Nasution, A. (2019). Preliminary phytochemical screening of different solvent extracts of flower and whole plant of Wedelia biflora. IOP 
Conference Series: Materials Science and Engineering. 3rd Nommensen International Conference on Technology and Engineering 2019 (3rd NICTE) 25-26 July 2019, Nommensen HKBP University, Indonesia.

${ }^{\mathrm{c}}$ Mardina, V., Mastura, Hamdani, Sufriadi, E. (2020). Flower of Sphagneticola trilobata (L.) J.F Pruski from Aceh, Indonesia: Antioxidant and Cytotoxic Activity on HeLa Cells. IOP Conf. Series: Materials Science and Engineering 1007 (2020) 012182. 3rd TICATE 2020

Mardina V., Yusof F., Alam, M.Z. (2015). Statistical optimization of physicochemical factors for protease production by Bacillus licheniformis on skim latex serum fortified media. Journal of Engineering Science and Technology sp issue 6 (1): $42-52$

Mohamad, R., Widyatuti, N., Suradikususmah, E., Darusman, L.K. (2012). Aktivitas antioksidan, kadar fenol dan flavonoid total dari enam tumbuhan obat Indonesia, Jurnal Trad Met, J, 18: 29 34

Muharni, Fitrya, Farida, S. (2017). Uji aktivitas antibakteri ekstrak etanol tanaman obat Suku Musidi Kabupaten Musi Banyuasin, Sumatera Selatan. Jurnal kefarmasian Indonesia, 7 (2): $127-135$

Ngajow, Mercy, Jemmy A.V. (2013). Pengaruh antibakteri ekstrak kulit batang matoa (pometia pinnata) terhadap Staphylococcus aureus secara in vitro. Jurnal MIPA UNSTRAT Manado, 3 (2):

Novitaria, Andi, H.A., Destiarti, L. (2016). Isolasi dan karakteristik golongan senyawa fenolik dari kulit batang tampoi (Baccaurea macrocarpa) dan uji aktivitas antioksidan. Jurnal KK, 5(2): $27-32$

Purnamasari, Fita, R., Susilo. Uji daya hambat ekstrak etanol kulit buah terong ungu
(Solanum melongena L.) terhadap Staphylococcus aureus dan Escherichia coli. Jurnal inovasi teknik kimia, 3 (1):

Rohdiana, D., Arief, D.Z., Budiman, A. (2013). Aktivitas penghambatan pertumbuhan bakteri Escherichia coli oleh berbagai jenis teh dan seduhannya. Jurnal Penelitian Teh dan Kina, 16 (1) :37 - 44

Tirtana, E. Idiawati, N. Warsidah, Jayuska A. (2013). Analisa Proksimat, uji Fitokimia dan aktivitas antioksidan pada buah tampoi (Baccaurea Macrocarpa). JKK, 2 (1): $42-45$

Tresia. (2016). Uji daya hambat antibakteri ekstrak umbi bawang merah (Allium ascalonicum ) terhadap pertumbuhan bakteri pembentukan karies gigi Streptococus mutans [skripsi] Yogjakarta : Fakultas Keguruan dan Ilmu Pendidikan

Yunus, R., Alimuddin, A.A., Ardiningsih, P. (2014). Uji aktivitas antibakteri ekstrak kulit buah tampoi (Baccaurea macrocarpa) terhadap bakteri Escherichia coli dan Staphylococcus aureus. Jurnal Kimia Khatulistiwa Vol 3 (3): 19-24 